\title{
REFOCUSING THE EUROPEAN UNION ATTENTION ON THE WESTERN BALKANS: THE IMPACT OF THE BERLIN PROCESS
}

\author{
Elton Tota \\ Kosovo Legal Services Company - Pristina, Kosovo \\ ORCID iD: https://orcid.org/0000-0002-5354-5245 \\ elton.tota@klsc.eu
}

\begin{abstract}
The expectations of the Western Balkans (WB) on the EU membership perspective could have been 'undermined' with the halt in the EU enlargement process as declared by the former European Commission President Jean-Claude Juncker in 2014. In the meantime, even though the WB countries were part of the EU's regional approach through the mechanism of Stabilization and Association Process (SAP) working on the implementation of the Acquis Communautaire, the slowing down of the integration process could have economic and political consequences and threaten the regional stability. This paper shows how the Berlin Process (2014) was the proper intergovernmental initiative taken by some EU Member States to keep alive the EU integration perspective of the WB, thus refocusing the EU attention on the challenges the WB was facing on the way towards EU integration.
\end{abstract}

Keywords: Western Balkans; Berlin Process; European Union; EU Integration; Regional Cooperation

\section{INTRODUCTION}

The EU membership perspective for central and eastern European countries including the Western Balkans (WB) has been confirmed and reconfirmed during the history of bilateral relations between the EU and these countries. A similar accession strategy used with the central and eastern European countries through the so-called 'Europe Agreements' was also applied with the Western Balkans through a mechanism called the Stabilization and Association Process with the eventual signature of 'Stabilization and Association Agreement'.

${ }^{1}$ In this paper, the term Western Balkans (WB) is used for the following group of countries: Albania, Bosnia and Herzegovina, Kosovo, Montenegro, North Macedonia and Serbia. 
However, due to the specific circumstances relating to historical, economic and political factors, the EU integration process of the WB proved to be long in time and challenging in terms of fulfilling the appropriate EU membership criteria. In 2014, "the building blocks of a decade of EU-Western Balkan policy were no longer solid enough to drive the enlargement process forward. Croatia's accession in 2013 did not result in a fresh push and resolve to move ahead with the remaining six countries who remained entangled in structural difficulties which had been exacerbated by the economic crisis" (Flessenkemper 2017, 25).

The Berlin Process (2014) launched for the Western Balkans aiming at supporting and keeping alive their EU membership perspective, represented a unique instrument by its nature since it was an intergovernmental initiative taken by some EU countries and at the same time enjoying the full support of the EU. All this, due to insufficient progress of the WB in the EU integration process and the continuing challenges they have been facing was a fact which brought a temporary halt in the EU enlargement process.

Therefore, the launch of the Berlin Process was designed as a necessary initiative in that regard - namely - to keep the WB countries committed and energized towards their common prospective project - that of EU membership. In the following, the paper will focus on issues such as: the confirmation of the European Perspective for the WB; the challenges hampering the $\mathrm{EU}$ integration of the $\mathrm{WB}_{\text {; }}$ the halt in the enlargement process and the possible consequences for the WB; the launch of the Berlin Process; a new impulse for connectivity and regional cooperation; the impact of the Berlin Process on the EU-WB summit held in Sofia (2018), as the first EU-WB summit held in the last fifteen years (since the Thessaloniki Summit in 2003) as another sign of refocusing the EU attention on the region while focusing on joint treatment of the challenges the WB were facing on their way towards the EU.

\section{CONFIRMING THE EU PERSPECTIVE FOR THE WESTERN BALKANS}

The EU membership perspective for the Central and Eastern European countries including the Western Balkans (WB) had firstly been confirmed with the Copenhagen Criteria $^{2}$ (1993) and then reconfirmed in the subsequent European Council meetings: in Corfu ${ }^{3}$ (1994), in Essen $^{4}$ (1994), in Cannes ${ }^{5}$ (1995) and in Madrid ${ }^{6}$ (1995). Since that time, the WB countries

\footnotetext{
${ }^{2 " T h e}$ European Council today agreed that the associated countries in Central and Eastern Europe that so desire shall become members of the European Union. Accession will take place as soon as an associated country is able to assume the obligations of membership by satisfying the economic and political conditions required" (European Council in Copenhagen, Conclusions of the Presidency, 21-22 June 1993, parag. iii, 13).

3"At the Copenhagen meeting in June 1993, the European Council decided that the associated countries of Central and Eastern Europe which wished to do so could become members of the European Union as soon as they were able to fulfil the relevant obligations" (The European Council Corfu, 24-25 June 1994, Conclusions of the Presidency, parag. 1.13, 14).

${ }^{4 "}$ The European Council confirms the conclusions of the European Councils in Copenhagen and Corfu that the associated States of Central and Eastern Europe can become members of the European Union if they so desire and as soon as they are able to fulfil the necessary conditions" (The European Council Essen, 9-10 December 1994, Conclusions of the Presidency, parag.1.13, 12).
} 
have consistently been in the sights of the EU. The EU presence through the implementation of different programmes of financial assistance aiming at the reconstruction and stabilization of the region has been of immense importance.

Additionally, it is clear that at the beginning of the 90 's considerable financial assistance by individual EU Member States as well as different international monetary institutions and donors to the WB countries has also been accorded. All this, was mainly and mostly dedicated to the recovery from economic backwardness, rule of law, stability, democracy and human rights in the WB as these countries had newly emerged from earlier economic and political systems and also suffering the consequences of wars in Yugoslavia which resulted in its dissolution.

In the following years, the EU launched an intensive approach for the WB through the Stabilization and Association Process (SAP 1999) as a new mechanism of financial assistance accompanied with the prospect of EU integration. Achieving contractual relations - the signature of an eventual Stabilization and Association Agreement (SAA) between the EU and the respective WB country was the core element of the SAP. The SAA itself consisting of respective rights and obligations represents the roadmap for the associated countries on their way towards the EU. Following on from the SAP, the EU integration perspectives for the WB had also been confirmed in subsequent EU-WB summits and in this regard, the EU "reaffirms the European perspective of the countries participating in the Stabilization and Association Process and their status as potential candidate for membership in accordance with Feira conclusions" (Zagreb 2000, 2). The EU integration perspective for the WB was also confirmed when it was stated that the EU "effectively support(s) the European perspective of the Western Balkan countries, which will become an integral part of the EU, once they met the established criteria" (Thessaloniki 2003, 8).

\section{THE CHALLENGES HAMPERING THE EU INTEGRATION OF THE WESTERN BALKANS}

In the SAP as the mechanism used for the gradual EU integration of the Western Balkans, the progress ahead has been assessed based on the individual efforts of each country and depended on fulfilling certain given criteria. In practice, the WB countries have been facing challenges touching many tangible issues, mostly interconnected to the past and affecting the present relations between them, and accompanied with consequences making

\footnotetext{
${ }^{5 " T h e ~ p r e p a r a t i o n ~ o f ~ t h e ~ a s s o c i a t e d ~ c o u n t r i e s ~ f o r ~ i n t e g r a t i o n ~ i n t o ~ t h e ~ i n t e r n a l ~ m a r k e t ~ i s, ~ a s ~ w a s ~ a f f i r m e d ~ b y ~ t h e ~ E s s e n ~ E u r o p e a n ~ C o u n c i l, ~ t h e ~}$ main element of the strategy of preparation for accession. The associated countries themselves regard such preparation for integration into the internal market as a priority" (The European Council Cannes, $26-27$ June 1995, Conclusions of the Presidency, parag. 1.32, 17).

${ }^{6 " T h e}$ European Council also confirms the need to make sound preparation for enlargement on the basis of the criteria established in Copenhagen and in the context of the pre-accession strategy defined in Essen for the CCEE; that strategy will have to be intensified in order to create the conditions for the gradual, harmonious integration of those States, particularly through the development of the market economy, the adjustment of their administrative structures and the creation of a stable economic and monetary environment" (The European Council Madrid, 15-16 December 1995, Conclusions of the Presidency, parag. 1.25(6), 18).
} 
their EU integration perspective to be challenged. On the way towards the EU membership, the most challenging issues for the WB countries, which simultaneously proved to be the key components, are also provided for by the SAA (Stabilization and Association Agreements) as in the following: Political dialogue (Title II, SAAs); Regional cooperation (Title III, SAAs); Approximation of laws, law enforcement and competition rules (Title VI, SAAs); and the area of justice freedom and security (Title VII, SAAs). While progress in three of the key components is mainly dependent on the internal efforts of the WB countries, when it comes to the regional cooperation - this is the field where the common efforts of the countries concerned have been necessary - and in fact where the lack of cooperation among the WB has mostly and permanently been evident. Such a lack of cooperation has coexisted and occasionally prevailed over the ongoing joint regional initiatives, conferences and summits in which the Western Balkans became part, such as:

- The Organization of the Black Sea Economic Cooperation (BSEC, 1992);

- The South-East European Cooperative Initiative (SECI, 1996);

- The South-East European Cooperation Process (SEECP, 1996);

- The Stability Pact for South Eastern Europe (1999);

- Adriatic lonian Initiative (All, 2000);

- The Danube Cooperation Process (DCP, 2002).

In this regard, the above mentioned regional initiatives in which the WB have taken part, have always enjoyed unequivocal EU support and in fact some of them were held with the EU initiative, thus transforming the EU into the main mechanism to increase the regional cooperation in the Western Balkans. Furthermore, it should be taken into account that the regional cooperation has always been considered as key element of EU integration in which the WBs should pay particular attention as a field where substantive progress is immediate. This has been an expressed EU demand in all the summits and initiatives relating to the European integration of the Western Balkans (such as: Copenhagen Criteria, 1993; Stability Pact, 1999; Zagreb Summit, 2000; Thessaloniki Summit, 2003). It is also emphasized that the regional cooperation and reconciliation is necessary and sine qua non condition to move forward, especially when taking into account the past of the region with conflicts and the consequences suffered. Regional cooperation in the western Balkans is:

- needed as a crucial ingredient of stability;

- a catalyst for reconciliation, good-neighborliness and good political relations;

- about helping overcome nationalism and intolerance and promoting mutual understanding and political dialogue in the region (European Commission 2005, 4).

Nevertheless, as the European Parliament (in 2015) had noticed, the EU strategy to the WB based on a regional approach being implemented through the SAP including in itself a set of components such as: trade liberalization, financial assistance, security dimension focused on cooperation in the area of justice, freedom and security as well as a regional 
dimension of increasing regional cooperation and good-neighborly relations, reconciliation in the Western Balkans, and on the other hand imposing set of politically sensitive conditions, an increased focus on good governance criteria and the redefinition of the existing monitoring mechanisms were a heavy load for the WB on their way towards the EU. However, some sixteen years after the launch of the Stabilization and Association Process with the EU, Western Balkan countries (apart from Croatia, which managed to join in 2013) are still far away from EU accession (European Parliament 2015, 13-14). Still, fulfilling the membership criteria remains a key element of the EU enlargement policy and at the same time the biggest challenge for the Western Balkans. A "credible enlargement policy is a geostrategic investment in peace, stability, security and economic growth in the whole of Europe. The EU and its partners aspiring to membership face common opportunities but also challenges like migration, organized crime and terrorism. Preparing the countries concerned to meet all membership requirements continues to be one of the EU's key political priorities" (European Commission 2019, 10-11).

\section{THE HALT IN THE ENLARGEMENT PROCESS AND ITS IMPACT ON THE WESTERN BALKANS}

The progress achieved by the WB countries toward fulfilling the EU accession criteria has been limited. It may be said that since the launch of the SAP (1999), with the exception of Croatia's EU membership (1 July 2013), in the EU-WB relations, the only remarkable progress achieved by the Western Balkans is the successful completion of the visa liberalization process. Even though, not including Kosovo which is still under the EU visa regime, all the other WB countries, Montenegro, North Macedonia and Serbia (2009) as well as Albania and Bosnia Herzegovina (2010) have achieved that. Nevertheless, with regard to the EU accession process, all the WB countries with no exception have been facing obvious difficulties on their way forward. The lack of appropriate progress was pointed out by the European Commission in 2014 which consequently announced a five year halt to the enlargement process. ${ }^{7}$ It should be taken into account that the enlargement is historically considered as one of the most successful of the EU's foreign policies and an effective transformation mechanism for all the Central and Eastern European countries as it has contributed to the consolidation, development and properly addressing their political, legal and economic challenges on their way towards the EU. And, on the other hand, for the WB itself, the EU presence in the region is highly important even in terms of stability and security.

\footnotetext{
${ }^{7 " I n}$ the next five years, no new members will be joining us in the European Union. As things now stand, it is inconceivable that any of the candidate countries with whom we are now negotiating will be able to meet all the membership criteria down to every detail by 2019. However, the negotiations will be continued and other European nations and European countries need a credible and honest European perspective. This applies especially to the Western Balkans. This tragic European region needs a European perspective. Otherwise the old demons of the past will reawaken" (Jean - Claude Junker, Speech 14/567, EP Plenary Session, Strasbourg, 15 July 2014).
} 
The declared 'halt' in the EU enlargement process could have been a negative signal to the Western Balkans in their expectations and continuing efforts towards achieving the standards for EU membership. In the "medium term, this message could negatively influence the commitment of the region's political elites to implement the reforms that the EU has demanded, as well as negatively impact support for European integration among the population" (European Parliament 2015, 12). Therefore, in order to keep alive the European perspective of the region, in circumstances when the enlargement process was declared temporarily halted, an intergovernmental initiative such as the Berlin Process (2014) has been welcomed as a clear sign and message to the Western Balkans that their EU membership perspective remains priority and the process will continue.

\section{THE BERLIN PROCESS}

The Berlin Process was launched as a supporting complementary mechanism for the WB in their efforts towards the EU. The Berlin Process "is based on three main pillars: (i) regional political cooperation and consolidation, including bilateral dispute resolution; (ii) improved economic cooperation, with a particular emphasis on connectivity in the energy, transport and digital domains; (iii) people-to-people relations with a focus on young people and cooperation with civil society" (Flessenkemper 2017, 27). The Berlin Process firmly underlines the crucial role and the achievements of the EU enlargement policy in the WB and unanimously supports the prospect of European integration for the countries of the Western Balkans (Berlin 2014, 1).

Not being an EU mechanism or initiative, but an intensive intergovernmental cooperation initiative taken by some EU countries (Germany, Austria, France, Croatia, Italy, and Slovenia), the Berlin Process aimed to facilitate the EU integration process for the WB by consolidating efforts and increasing regional cooperation among them. The Berlin Process "did not create a new Acquis that would replace the EU's. It did not rest on new institutions, nor did it provide new funding capacities. It was launched as an additive and complementary process, essentially anchored in the EU's normative approach to membership and regional competitive and growth strategy" (Marciacq 2017, 8). The Berlin Process was designed as a multi-dimensional tool consisting of successive WB summits where the participating states of - the 'Western Balkan Six - WB6' (Albania, Bosnia and Herzegovina, Kosovo, Montenegro, North Macedonia and Serbia) and - the 'six EU Member States' agreed to increase cooperation in the following issues:

- Intensifying regional cooperation, strengthening good governance, increasing prosperity via sustainable economic growth (Berlin 2014, 2-4);

- Regional cooperation and the solution of bilateral disputes, rule of law and good governance, fight against extremism and radicalization, migration, economic prosperity and connectivity, market integration - trade facilitation, mobility and joint 
growth initiatives, youth, education, science and research, civil society (Vienna 2015, 18);

- Connectivity and trade, priorities to the youth, migration and the fight against terrorism and radicalization (Paris 2016, 3-7);

- Connectivity, regional economic integration and development, private sector and SMEs development, human connectivity - youth, Governance, rule of law and prevention and fight against corruption, science, outstanding bilateral issues, civil society, fight against terrorism, extremism, radicalization and organized crime, preventing irregular migration (Trieste 2017, 3-10);

- Prosperity and connectivity, regional cooperation, security, youth and civil society. While in the context of decisive issues in further enhancing regional cooperation, the signature of the following joint declarations is considered to be of significant importance: Joint Declaration on Regional Cooperation and Good-Neighborly Relations in the Frame-work of the Berlin Process; Joint Declaration on Missing Persons in the Framework of the Berlin Process; Joint Declaration on War Crimes in the Framework of the Berlin Process (London 2018, 1-2);

- Economy, connectivity, good-neighborly relations, reconciliation and outstanding bilateral issues, security. Of a certain importance is the signature of the joint Declaration of Western Balkans Partners on Roma Integration within the EU Enlargement Process and also endorsement of other joint commitments taken in the WB (Poznań 2019, 1-11).

It is clearly evident that the Berlin Process aimed at confirming the continuing EU commitment to the WB in order to keep alive the EU integration perspective for the region and to increase regional cooperation among the WBs focusing on a wide range of areas to implement investment projects which effectively addresses the most needs of the region.

The Berlin Process gave a new impulse to the regional cooperation among the WB. Regarding the Berlin Process, "it is the presence of key EU Member States providing the highest level of political support to the initiative that makes it different from other regional cooperation initiatives $(\mathrm{RCl})$. The clear and unambiguous commitment of those Member States (MS) to the Enlargement in the Balkans, and the immediate embrace they found from the WB6 politicians, defined the success of the initiative, as compared with other RCl" (Hackaj A; Hackaj K 2018, 15). Through this process, certain EU Member States not only initiated the process but also became involved in it by taking part in a series of WB summits where the common challenges and unresolved matters would continuously be discussed as they are key issues for their common EU future. In spite of "its shortcomings, the Berlin Process has 'invigorated' regional cooperation in a way that none of the more than seventy initiatives linking state and non-state actors of social development in the region have previously managed to do" (Marjanović Rudan 2017, 8). 


\section{A NEW IMPULSE FOR CONECTIVITY AND REGIONAL COOPERATION}

The launch of the Berlin Process was a way to confirm the EU's continued commitment to the region's accession and to give a new momentum to the enlargement process (European Parliament 2016, 2). In focus of the Berlin Process were issues of great importance for bringing the countries and the people of WB close to each other, discussing the issues of common interest and for their future movement towards the EU. With "its annual summits the process has established itself as a new framework to advance regional cooperation, connectivity, and address questions not covered by EU accession directly, such as youth cooperation, 'reconciliation' and bilateral disputes. The method is entirely intergovernmental" (Flessenkemper 2017, 24).

Taking into consideration the obstacles to regional cooperation and good-neighborly relations among the WB, the Berlin Process aimed at discussing the existing open issues such as: border disputes, political disputes and minority rights among the WB countries. Therefore, in this regard the respective declarations were signed (attached to the final declarations of the London Summit 2018 and Poznań Summit 2019). Among others, given the importance of connectivity for economic growth, educational projects and youth exchange, the Berlin Process also provided investments in infrastructure (i.e. 10 approved projects), respectively in the areas of transport and energy. It is evident that some of the open issues among the WB have been proven to be difficult to solve for decades, therefore the Berlin Process as an initiative was seen as creating opportunities for dialogue, cooperation and a common EU future and to 'remind' the WB of the common values the EU shares and encourage them to work forward together. However, "the question remains whether and to what extent the governments of the Western Balkan countries are committed to substantial use of opportunities created by this process" (Nicić; Nechev; Mameledžija 2016, 25).

Taking into account that the Berlin Process was a time-limited initiative foreseen to take place over four years (2014-2018), even the expectations that it may cover and deal with all the challenging issues in the region were not very high. Looking "closely at the Berlin Process agenda it is clear that there is much at stake making it difficult - if not impossible - to tackle the regional challenges in such a short timeframe and in the intricate multilateral environment" (Emini 2018, 9-10). But, above all, one should bear in mind that the Berlin Process despite its limitations achieved its main objective. It has managed to keep the key EU Member States focused on the region, created such opportunities and opened up the way towards connectivity and cooperation among the WB by giving a new impetus from an exclusively designed process for them and covering issues of core importance for the region itself and for EU integration. It has "succeeded in bringing the political leaders of the region to the same table each year, but also in mobilizing regional initiatives and in setting up the most comprehensive platform so far for regional cooperation between civil society, young people, business entities and of other non-state stakeholders" (Marjanović Rudan 2017, 8). 


\section{THE IMPACT OF THE BERLIN PROCESS ON THE SOFIA SUMMIT}

As a follow-up to the Berlin Process, the EU-WB Summit held in Sofia (on 17 May 2018) was a clear sign of EU attention to the Western Balkans and that the integration of WB remains a priority for the EU itself. Since the Thessaloniki Summit (2003), it was the first time the EU was back to hold a summit with the WB with the clear purpose reconfirming the EU perspective to the region. ${ }^{8}$ In order to keep the EU and the WB close, the Sofia summit aimed at further improving the relations between the parties and therefore to increase cooperation in the following issues:

- Strengthening support to the rule of law and good governance;

- Reinforcing engagement on security and migration;

- Supporting socio-economic development and putting a special focus on youth;

- Increasing connectivity;

- Setting up a Digital Agenda for the Western Balkans;

- Supporting reconciliation and good-neighborly relations in the Western Balkans (Sofia 2018, 4-7).

In addition to reaffirming the European perspective for the region, the EU has been aware of the challenges the WB has been going through and therefore has shown readiness to share such challenges together by properly and effectively addressing them. As such, it was also concluded in the Sofia Declaration as it reaffirms the EU determination to strengthen and intensify its engagement at all levels of support on issues such as: democracy and the rule of law, especially the fight against corruption and organized crime, good governance, as well as respect for human rights and rights of persons belonging to minorities; goodneighborly relations, regional stability; the implementation of the Acquis; security challenges; Common Foreign and Security Policy (Sofia 2018, 1-3). The EU-WB Sofia summit was encouraged by the Berlin Process; it is evident that it has absorbed some of the Berlin Process' topics. It means that over time the Berlin Process has proven its impact on the Western Balkans countries with regard to the issues in which they have to become focused on as they are important for the EU integration.

\section{CONCLUSION}

The Berlin Process for the Western Balkans was launched as an intergovernmental four-year platform composed of annual summits aiming at increasing regional cooperation and contributing to the European Integration process through advancing the EU agenda in three new agreed dimensions: economic growth and connectivity, good-neighborly relations

\footnotetext{
"'Today we reaffirmed our mutual commitment to the European perspective for the whole region. As I said during my recent visit to the region, the European Union is and will remain the most reliable partner of the entire Western Balkans" (Remarks by President Donald Tusk after the EU-Western Balkans summit, Council of the EU, Press 258/18, 17.05.2018).
} 
and regional cooperation, and civil society development and people to people connectivity. When the further EU enlargement with Western Balkans was declared temporarily at a halt due to the WB insufficient progress in the accession criteria, the Berlin Process was proven to be the right initiative which provided a set of issues to work on. Through the areas of cooperation and the themes of discussion in the Berlin Process annual meetings, it has achieved that bridges of cooperation among the WB countries have been built and questions not covered directly by EU accession have been addressed. Furthermore, the Berlin Process also served as a platform where regional countries promoted and exchanged their views with regard to common challenges they are faced with. The Berlin Process contributed to the region by refocusing the EU attention on it and putting the region continuously into focus of active developments in the light of the EU integration process. The Berlin Process to some extent impacted the subsequent EU-WB Sofia summit and will also have its place in the possible contribution to transforming the EU's enlargement policy. 2at 


\section{REFERENCES}

1. Chair's Conclusions of the Heads' meeting of the London Western Balkans Summit, 10 July, London, 2018.

2. Council of the EU, Press Statements and Remarks, Remarks by President Donald Tusk after the EU-WesternBalkans summit, 258/18, 17 May, 2018.

3. Declaration by the Italian Chair, Trieste Summit Western Balkans, 12 July, Trieste, 2017.

4. EU- Western Balkans Summit, Sofia Declaration, 17 May, 2018.

5. European Commission, "2019 Communication on EU Enlargement Policy", 29May, Brussels, 2019.

6. European Commission, "Regional cooperation in the western Balkans, A policy priority for the European Union", 2005.

7. European Commission, Jean - Claude Junker, Speech 14/567, Strasbourg, 15 July 2014.

8. European Parliament, "The Western Balkans and EU Enlargement: Lessons learned, ways forwards and prospects ahead", 5November, Belgium, 2015.

9. European Parliament,"The Western Balkans' Berlin process:A new impulse for regional cooperation" Briefing, 4 July, 2016.

10. Emini, Donika, 2018, "Berlin Process: an additional mile toward EU Membership?", published by KCSS (Kosovar Center for Security Studies).

11. Final Declaration, Zagreb Summit, 24 November, 2000.

12. Final Declaration by the Chair of the Conference on the Western Balkans, 28 August, Berlin, 2014.

13. Final Declaration by the Chair of the Vienna Western Balkans Summit, 27August, Vienna, 2015.

14. Final Declaration by the Chair of the Paris Western Balkans Summit, 4 July, Paris, 2016.

15. Flessenkemper, Tobias. 2017. "The Berlin Process: resilience in the EU waiting room", In Resilience in the Western Balkans, edited by Sabina Lange, ZoranNechev and Florian Trauner, published by EU Institute for Security Studies.

16. Hackaj, Ardian., Hackaj, Krisela, 2018, "The Berlin Process 2014-2018", published by Cooperation and Development Institute.

17. Nicić, Jovan.,Nechev, Zoran., Mameledžija, Selma. 2016. The Berlin Process and Regional Cooperation in the Western Balkans: how to make agreements more effective and efficient? Policy Brief, published by European Fund for the Balkans.

18. Marjanović Rudan, Anna, 2017. "The Berlin Process as a Framework for Concluding the Agreement on RECOM" In Reconciliation through the Berlin Process: The Role of RECOM, edited by: Nataša Kandić, Ana Marjanović Rudan, Igor Novaković, Jelica Minić, Sven Milekić, 6-8, Policy Brief, published by The Coalition for RECOM.

19. Marciacq, Florent. 2017. "The EU and the Western Balkans after the Berlin Process: Reflecting on the EU Enlargement in Times of Uncertainty", published by Dialog Südosteuropa. 
Journal of Liberty and International Affairs | Vol. 6, No. 2, 2020 | elSSN 1857-9760

Published online by the Institute for Research and European Studies at www.e-jlia.com

20. Thessaloniki European Council, Presidency conclusions, 19-20 June, 2003.

21. The European Council in Copenhagen, Conclusions of the Presidency, 21-22 June, 1993.

22. The European Council Corfu, Conclusions of the Presidency, 24-25 June, 1994.

23. The European Council Essen, Conclusions of the Presidency, 9-10 December, 1994.

24. The European Council Cannes, Conclusions of the Presidency, 26-27 June, 1995.

25. The European Council Madrid, Conclusions of the Presidency, 15-16 December, 1995.

26. Western Balkans Summit Poznań, Chair's conclusions, 5July, Poznań, 2019. 